\title{
Integrative ecological management of coastal marine and limans ecosystems of Ukraine
}

\author{
Galyna Minicheva ${ }^{1, *}$, Viktor Demchenko ${ }^{1}$, and Yevhen Sokolov ${ }^{1}$ \\ ${ }^{1}$ Institute of Marine Biology of the National Academy of Sciences of Ukraine, 6 Udelny lane, 65044, \\ Odessa, Ukraine
}

\begin{abstract}
Based on the experience of managing coastal marine, and limans ecosystems of Ukraine, the theoretical scheme of Integrative Ecological Management is considered. The scheme includes the "Basic Diagnostic" block for which the key tools are: Basin Assessment, Ecosystem Approach and Ecosystem Services. Geo-information Technologies are demonstrated in order to assess the catchment areas of some limans and coastal marine ecosystems of Ukraine. With the ecosystem approach, it is necessary to use functional indicators for assessing autotrophic, heterotrophic and decomposer communities of the ecosystem, the bind of which is associated with Ecological Status of the water body. It is indicated that an important goal of environmental management is reducing the intensity of anthropogenic flows of substance and energy, which cause destruction of the ecological balance and devaluation of ecosystem services. For the second block of the scheme "Decision Making" it is proposed to use Priority Management Algorithm principle as an effective tool which allows to achieve the target maximum at minimal cost. At the final stage of the "Target Result", recommendations that are offered to stakeholders at the local, regional and national level must achievement the main objectives of the Integrative Ecological Management of coastal marine ecosystems and limans.
\end{abstract}

\section{Introduction}

The length of the Azov-Black Sea coastline in Ukraine is about $1500 \mathrm{~km}$, which is adjacent to about 25 large limans of the northwestern Black Sea and Azov region. A huge part of coastal marine ecosystems and limans falls under the natural protection territories of the Azov-Black Sea region, is given the status of wetlands of international importance, and is considered an element of the Emerald network.

Although, they are important from the social and economic sides as well. Besides, these waters have recreational value, more than 15 million people come to the coast for vacation each year.

The combination of high intensity of nature processes and peak anthropogenic pressure in the ecosystems of the contact zone is the reason why the most valuable contour

\footnotetext{
* Corresponding author: minicheva@ukr.net
} 
ecosystems also become the most vulnerable, and thus require environmental management in the first place. The value, vulnerability and locality of coastal waters and limans form an objective basis for ecological management application based on systemic principles, and must be accompanied by the achievement of Good Ecological Status (GES) and Sustainable Development [1].

The highest life concentration is observed in the land-sea contact zones, and so is the main part of natural resources reproduction [2]. In this regard, application of Integrative Ecological Management (IEM) to highly productive and anthropologically loaded contour ecosystems is especially relevant for coastal marine ecosystems and limans of Ukraine.

The main target of the Northern Black Sea and Priazovian waters management was mainly to obtain high fish production. In some cases, recreational, balneological, ameliorative and industrial problems were tackled. In general, the limans of the Ukrainian sector of the Black and Azov Seas have been used as landfills for various management decisions that were implemented without an integrative approach and without taking into account current negative regional processes. Such decisions thus lead to large-scale environmental crises which are accompanied by ecosystem degradation and destruction of their natural resource potential $[3,4]$.

In order to achievement GES in accordance with the EU Water Framework Directive (WFD) [5] and Marine Strategy Framework Directive (MSFD) [6] requirements along with the implementation of sustainable development [7-11], according to the ideology of Blue Grows [12], for coastal marine ecosystems and limans of Ukraine, it is necessary to develop methodological principles of IEM, taking into account natural regional features and the prevailing regional anthropogenic impact.

The purpose of this work is, based on the experience of managing the marine coastal and limans ecosystems of Ukraine, to consider the theoretical scheme of IEM, including the principles of Basin Assessment and Ecosystem Approach, the ultimate goal of which is to achieve Good Ecological Status, Sustainable Development and Socio-Economics Benefits.

\section{Material and methods}

Basin assessment of coastal marine and liman ecosystems of Ukraine was performed using remote sensing data: spectrozonal satellite images (Landsat8, Sentinel2) and digital terrain models SRTM (NASA Shuttle Radar Topography Mission) with the processing by QGIS and ArcGis, which allowed to conduct a comprehensive functional environmental assessment of anthropogenic pressure with a diagnosis of the most vulnerable areas of coastal territorial complexes and parts of the hydrographic network of watersheds. Assessment of the hydroecological potential of liman and coastal ecosystems was carried out on the based on the index of natural resistance (INR), which consists of eight combined limnological characteristics reflecting the peculiarities of the inflow and distribution of the material-energy flow in the ecosystem - water exchange with the sea, the capacity of the water mass in relation to the material energy flow, the catchment area influence on autochthonous, hydrodynamic processes [13].

Artificial Force Index (AFI) was applied in order to assess the anthropogenic impact on the intensity of the primary production process (the degree of anthropogenic eutrophication).

The AFI was calculated as the difference between the ESC categories (High, Good, Moderate, Poor, Bad), morphological and functional indices of benthic vegetation (macrophytobenthos), and natural sustainability [13]. 


\section{Results and discussion}

As a result of WFD and MSFD tandards implementation in Ukraine it became possible to assess the current ecological state of coastal water bodies and largest limans in the ESC categories based on morphological and functional indicators of benthic vegetation [14] (Fig.1). Due to this analysis, an ESC was obtained for most of the region's water areas, which makes it possible to identify the most problematic water bodies that primarily require complex management to achieve GES.

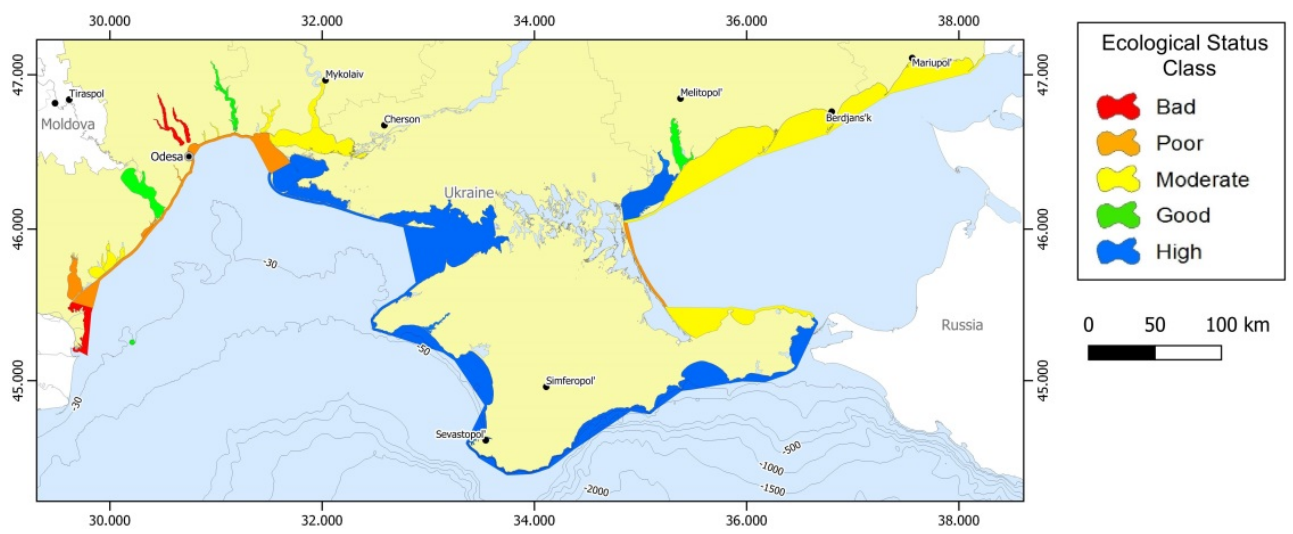

Fig. 1. ESC categories for water bodies of the Ukrainian sector of the Black and Azov Seas.

The principles of IEM are not currently widely used for water bodies in the Northern Black Sea and Azov regions. Plans for the management of some river basins are implemented only partially [15-17]. For limans, some attempts to develop management plans have been made as part of management development plans for wetlands of international importance or regarding hydrological or hydrochemical regimes management [18]. Given the lack of systemic solutions in the management of liman and coastal marine waters, there is a need to develop a holistic step-by-step scheme that will comprehensively address ecological management using a basin approach, Ecosystem Approach and Ecosystem Services (Fig. 2).

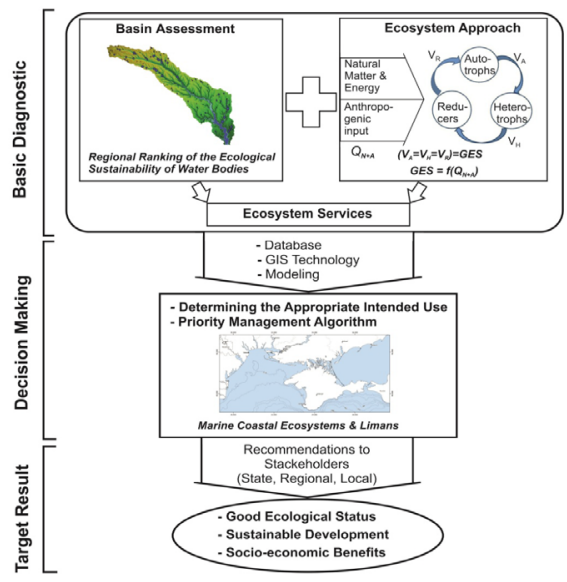

Fig. 2. Scheme of Integrative Ecological Management of the coastal marine and liman ecosystems. 
The proposed figure consists of three blocks: the block of Basic Diagnostics, the block of Decision Making, and the block of Target Result.

\section{Basic Diagnostic}

The block of Basic Diagnostics provides for the necessity of carrying out complex hydroecological and socio-economic research in order to receive primary state indicators. Its implementation should be based on three principles: Basin Assessment of the water body, Ecosystem Approach, assessment of the Ecosystem Services (see Fig. 2).

The Basin Approach assumes that the catchment area, together with the reservoir, forms a holistic geo-ecosystem with transit-accumulative functions and directly affects the formation of the ESC of hydroecosystems. According to the WFD, the river basin is the main territorial unit when it comes to protection of the aquatic environment. Planning a sustainable landscape management structure includes:

- spatial zoning, taking into account the morphology of the terrain and the spatial location of lands among themselves;

- formation of a sustainable ecological framework along with an ecological network consisting of environment-stabilizing and refugium lands;

- creation of an environment-protective regime.

For Tyligulskyi liman, a differential (with allocation of sub-basins) basin assessment of the anthropogenic state transformation of natural territorial complexes [19] and the the hydrological regime violation level in connection with the hydrographic network pond regulations was carried out (Fig. 3).

For marine waters, an assessment of the landscape state and economic structure of coastal territorial complexes was carried out on the example of Yagorlytsky and Tendrovsky bays. Terrestrial coastal biogeocenoses of bays are characterized by high mosaicism and preservation, being in a natural and quasi-natural state (Fig. 4). Compared to Yagorlytsky Bay, Tendrovsky Bay is characterized by a greater transformation of terrestrial natural territorial complexes into croplands with irrigation systems, which is reflected in lower ESC categories determined by the average specific surface area of bottom vegetation populations. Areas under nature conservation programs tend to have the highest degree of preservation of natural conditions.
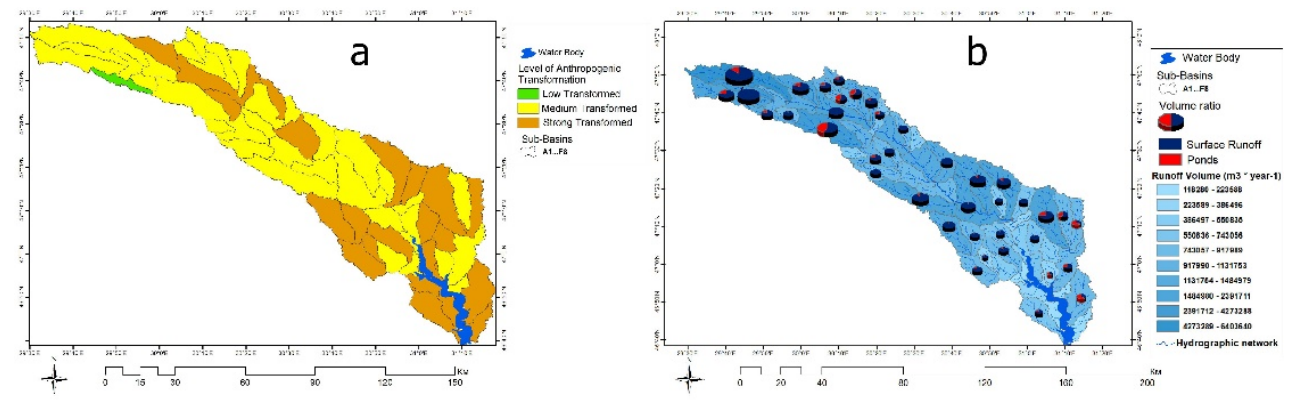

Fig. 3. Differential ecological assessment of the Tyligulskyi liman watershed: a - the level of transformation of natural territorial complexes; $b$ - the ratio of ponds and natural runoff. 

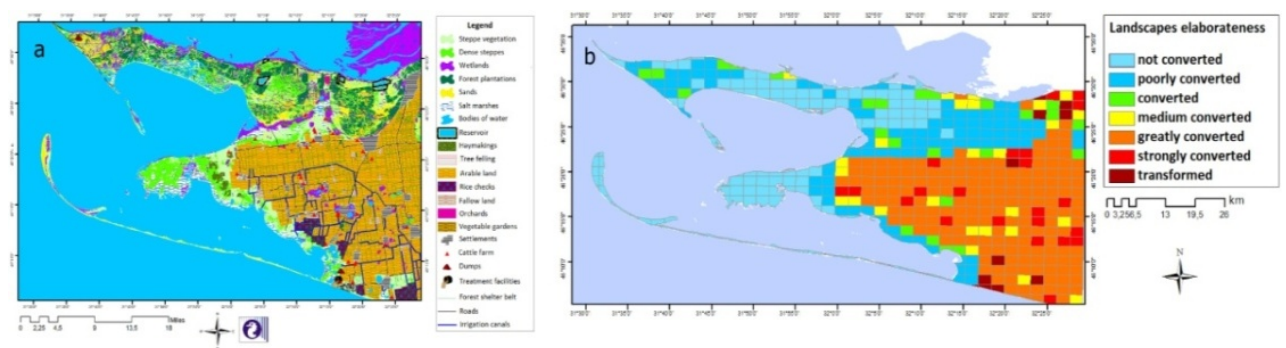

Fig. 4. Assessment of coastal territorial complexes of Yagorlytsky and Tendrovsky bays: a landscape-economic structure; $\mathrm{b}$ - distributional rate of anthropogenic transformation.

Based on basin assessment, taking into account hydrological and morphological conditions, land conditions, regulation of watercourses and environmental legislation, it is possible to develop geo-informational layers for reorientation of land use structures, increasing the area of protective lands, land allocation with extensive land use, which makes it possible to provide consolidated assessment of existing ecological problems of water areas.

Ecosystem Approach. The main idea of the ecosystem approach lies in the fact that natural and anthropogenic components are considered to be interrelated elements of a holistic system. At the same time, the main goal of ecological management is to maintain the structure and functioning of the natural system, while the ecosystem itself simultaneously provides its services and social benefits that are essential to society [20]. In fact, successful ecosystem approach application is centered around the concept of "health" by achieving both the health of the nature system and the health of the human system [21].

Since the main goal of management of the system's natural component is to achieve GES, the indicators on the basis of which the aquatic ecosystem is assessed should reflect the intensity of autotrophic, heterotrophic and decomposer functions and their bind in time and space. One of the integrative diagnostic criteria of the GES of an aquatic ecosystem may be the balance of the ecological formation function, transformation, and destruction of organic matter (see Fig. 2). At the same time, an equilibrium of the ecosystem is a derivative of the total flow input of natural and anthropogenic matter and energy $\left(Q_{N+A}\right)$. According to GES, the anthropogenic component intensification - $\mathrm{QA}_{\mathrm{A}}$ is one of the most common causes of the ecological balance disturbance, which manifests itself in the ecosystem eutrophication and thus a sharp decrease in the complex of ecosystem services. Therefore, one of the most effective mechanisms of IEM of coastal marine ecosystems and limans is the principle of containment anthropogenic flows that incoming to ecosystem, which not only reduce biological diversity, destroy the interconnection of ecological processes, but also devalue socio-economic services.

Ecosystem Services as a tool for the basic diagnostics stage of coastal marine waters and limans aims to assess the value of aquatic waters and to provide their ecological, social and economic features. Among many ecosystem services are those that provide resources (food, water, timber, raw material), regulate processes in ecosystems (climate impact, flood and natural disasters control, water quality, etc.), provide cultural and social services (aesthetic and spiritual values of nature) and support ecosystem functioning (soil formation, photosynthesis, nitrogen cycle, etc.). At present, there are different methodological approaches for assessing ecosystem services. The Ramsar Committee, as part of wetland management, proposed a rapid assessment of ecosystem services. The practical RAWES approach (Rapid Assessment of Wetland Ecosystem Services) was created as a simple and rapid land assessment system that provides data from existing studies, yet does not contain 
detailed quantitative assessment [22]. A cost estimate should be used to achieve more efficient and quantitative assessment of ecosystem services [23,24].

The result of the Basic Diagnostics block is comprehensive data on the functioning of coastal marine waters or limans which provides the content of targeted, structured databases, uses the capabilities of Geo-information Technology and provides data for modeling ecological processes. Accumulation of information using the above three basic diagnostic tools allows advancing to the next stage of IEM - Decision Making.

\section{Decision Making}

The most important step in comprehensive environmental monitoring is Decision Making when it comes to determining the Appropriate Intendent Use of a water body. Decision Making is the choice of optimal actions from a set of existing alternatives. The options of choosing the most rational and effective solutions becomes one of the most important goals of management [25]. Among the various forms and methods of impact on the water body, this stage aims to find a balanced solution that will ensure the restoration of GES, sustainable use with environmental, social and economic benefits. At this stage it is necessary to implement an informational management system for the selection of strategic and operational decisions, which are based on management algorithms and chosen priorities. Priority Management Algorithm was proposed for the coastal waters and limans of the Azov-Black Sea region based on the assessment of hydroecological features and the current level of nature management, consisting of four blocks: - Administrative and Economic Control; Maintaining the Structure and Production Processes of the Biotic Component; Watershed Management; Artificial Control of the Hydrological Regime. Ecosystem stabilization and formation of a balanced nature management regime involves the implementation of all four management blocks, but in order to rationally and efficiently use the funds needed to implement these measures, a priority structure was proposed based on expert assessment of expected environmental performance of different blocks [26]. Using the principle of priority management permits to achieve the maximum target result with minimal economic costs.

\section{Target result}

The block of Target Result is final within the complex organization scheme of ecological management of coastal marine and liman ecosystems. It is based on sound recommendations for stakeholders at local, regional and national levels. The likelihood of stakeholders using the recommendations of IEM of water bodies will depend on the obviousness of obtaining natural and economic benefits. The end result of IEM, regardless of the intended use of the water body, should be an increase in ESC of water bodies, their sustainable development and socio-economic benefits.

\section{Conclusions}

The analysis of management experience of coastal marine and liman ecosystems of Ukraine and known European approaches to the assessment and management of water bodies allow to propose a theoretical scheme of IEM, which should include three consecutive blocks: Basic Diagnostic; Decision Making; Target Result. At the Basic Diagnostic stage, an important methodological condition is a combination of such methods: - Basin Assessment using WFD principles and modern Geo-information Technologies; - Ecosystem Approach with an integrative assessment of the natural and anthropogenic components of matter and 
energy flow, and an assessment of the ratio of functional indicators of autotrophic, heterotrophic and decomposer communities; Ecosystem Services using an estimate price assessment of the natural properties of the water body. The first stage implementation permits the formation of structured primary databases for Geo-information Technologies and modeling. At the second stage (Decision Making), an important goal is determining the Appropriate Intendent Use of the water body; the Priority Management Algorithm that allows achieving the maximum target result at the lowest economic cost is applied to accomplish the task. At the third, final stage (Target Result) for stakeholders at local, regional and national levels, recommendations that will quickly achieve GES, Sustainable Development and Socio-Economic Benefits should be developed.

\section{Reference}

1. HELCOM (2018). "Implementation of the Baltic Sea Action Plan 2018: Three years left to good environmental status," in Proceedings of the Brussels Ministerial Meeting, (Brussels: Baltic Marine Environment Protection Commission).

2. Zaitsev, Yu. (2006). Littoral concentration of life in the Black Sea area. J. of the Black Sea Mediter. Envir., 12, 113-128.

3. Tuchkovenko, Yu.S., Gopchenko, E.D. (Eds). (2011). Aktual'nyye problemy limanov severo-zapadnogo Prichernomor'ya, TPP.

4. Zaitsev, Yu.P., Alexandrov, B.G. (Eds). (2006). Severo-zapadnaya chast' Chornogo morya: (biologiya i ekologiya), Naukova Dumka, 351 -356.

5. European Council (2000). DIRECTIVE 2000/60/EC of the European Parliament and of the Council establishing a framework for the Community action in the field of water policy.

6. European Council (2008). DIRECTIVE 2008/56/EC of the European Parliament and of the Council establishing a framework for Community action in the field of marine environmental policy.

7. Kostetska, K., Khumarova, N., Umanska, Y., Shmygol, N., \& Koval, V. (2020). Institutional qualities of inclusive environmental management in sustainable economic development. Management Systems in Production Engineering, 28 (2), 1522. https://doi.org/10.2478/mspe-2020-0003

8. Mikhno, I., Koval, V., Shvets, G., Garmatiuk, O., \& Tamošiūnienė, R. (2021). Green Economy in Sustainable Development and Improvement of Resource Efficiency. Central European Business Review, 10(1), 99-113. doi: 10.18267/j.cebr.25

9. Koval, V., Mikhno, I., Trokhymets, O., Kustrich, L., Vdovenko, N. (2020). Modeling the interaction between environment and the economy considering the impact on ecosystem. E3S Web Conferences, 13002. https://doi.org/10.1051/e3sconf/202016613002

10. Prokopenko, O.V., \& Petrushenko, M.M. (2013). Systems-synergetic thinking to the environmental conflicts management at the territorial level. Marketing and Management of Innovations, 1, 254-266.

11. Arsawan, I.W.E., Koval, V., Rajiani, I., Rustiarini, N.W., Supartha, W.G. and Suryantini, N.P.S. (2020). Leveraging knowledge sharing and innovation culture into SMEs sustainable competitive advantage. International Journal of Productivity and Performance Management, (in press). https://doi.org/10.1108/IJPPM-04-2020-019

12. Eikeset, A.M., Mazzarella, A.B., Davíðsdóttir, B., Klinger, D.H., Levin, S.A., Rovenskaya, E., Stenseth, N.C. (2018). What is blue growth? The semantics of 
"Sustainable Development" of marine environments. Marine Policy, 87, 177-179. https://doi.org/10.1016/j.marpol.2017.10.019

13. Minicheva, G.G., Sokolov, E.V., Shvets, A.V. (2016). Otsenka prirodnoantropogennogo statusa pribrezhno-akval'nogo kompleksa Yagorlytskogo zaliva. Naukovi zapysky Ternopil's'koho natsional'noho pedahohichnoho universytetu imeni Volodymyra Hnatyuka: biolohiya, 3-4 (67), 74-84.

14. Minicheva, G. (2013). Use of the Macrophytes Morphofunctional Parameters to Asses Ecological Status Class in Accordance with the EU WFD. M. Eco. 9 (3), 5-21.

15. Sazonets, I., Pokul, O. (2015). Basin management as an effective government method of providing water resources rational use by enterprises of Ukraine. S.-econom. Res. Bul. 3 (58), 198-205.

16. Romashchenko, M.I., Hvesyk, M.A., Mykhaylov, Y.O. (Ed). (2015). Water Strategy of Ukraine for the period until 2025 year, Scientific foundations.

17. Klimchyk, O.M., Pinkina, T.V., Pinkin, A.A. (2018). Vprovadzhennya systemy intehrovanoho upravlinnya vodnymy resursamy za baseynovym pryntsypom. Sci. J. "ScienceRise", 4 (45), 36-40.

18. Loboda, N.S., Gopchenko, E.D. (Ed). (2016). Vodnyy rezhym ta hidroekolohichni kharakterystyky Kuyal'nyts'koho lymanu. TES..

19. Shishchenko, P.G. (1988). Applied physical geography. High School.

20. Elliott, M. (2011). Marine science and management means tackling exogenic unmanaged pressures and endogenic managed pressures. A numbered guide. Mar. Pollut. Bull, 62, 651-655. https://doi.org/10.1016/j.marpolbul.2010.11.033

21. Tett, P., Gowen, R.J., Painting, S.J., Elliott, M., Forster, R., Mills, D. K., et al. (2013). Framework for understanding marine ecosystem health. Mar. Ecol. Prog. Ser., 494, 127. doi: 10.3354/meps 10539

22. McInnes, R.J., Everard, M. (2017). Rapid assessment of wetland ecosystem services (RAWES): an example from Colombo, Sri Lanka. Ecosyst. Serv., 25, 89-105.

23. Degtyar, N.V. (2012). Suchasni metody ekonomichnoyi otsinky ekosystemnykh posluh. Effective economy. 2. http://nbuv.gov.ua/UJRN/efek_2012_2_45

24. Mishenin, E.V. Degtyar, E.V. (2015). Economics of ecosystem services: theoretical and methodological foundations. Marketing and management innovation, 2, 243-257.

25. Grabovetsky, B.E. (2010). Metody ekspertnykh otsinok: teoriya, metodolohiya, napryamky vykorystannya. VNTU.

26. Minicheva, G.G., Sokolov, E.V. (2015). Structure of the priority environmental management of the estuaries of the north-western Black Sea regio . Naukovi zapysky Ternopil's'koho natsional'noho pedahohichnoho universytetu imeni Volodymyra Hnatyuka: biolohiya, 3-4 (64), 446-459. 